\title{
Character Education through the Obligation to Wear Santri's Dress
}

\author{
Muhammad Sulthan Mazaya \\ International Standard Boarding School of Amantul Ummah \\ Mojokerto, Indonesia \\ msulthanmazaya@gmail.com
}

\author{
Hilda Ainissyifa \\ Department of Islamic Education \\ Universitas Garut \\ Garut, Indonesia \\ hildaainissyifa@uniga.ac.id
}

\begin{abstract}
Dress is a part of the wearer identity, which is believed that wearing a certain dress will affect the wearer's behavior and can reflect the wearer's emotion, which at the same time can affect the other people's emotions. This study is aimed at discussing the impact of wearing typical dresses of santri (cap and sarong) on the behavior of male students. This study applied descriptive analysis approach, which connects the phenomena (variables) of research based on observation facts that the researcher found in the site of study. The object of this research covers the students of International Standard Boarding School of Amantul Ummah, Mojokerto. The research findings showed that wearing typical dresses of santri has positive effect on the santri's behavior. This research recommends the habituation of santri's dresses with reward and punishment mechanism to control to the santri's obedience in pesantren environment.
\end{abstract}

Keywords—behavior; cap; dress; pesantren; sarong

\section{INTRODUCTION}

Education is a conscious effort that people apply as a formation process of intellectual and emotional fundamental skills. Education is not just a means of transfering knowledge, but more broadly, as a means of culture and value distribution [1]. The focus of education is directed to the formation of a superior personality by focusing on the maturing process of the quality of logic, heart, moral, and faith. The peak of education is achieving the perfection of life quality [2].

One of the main orientations of pesantren based-learning process in madrasah is the formation of santri's good behavior built upon religious norms. Behavior is controlled by the center of consciousness, most behaviors are the actions established, acquired, and learned through learning process [3].

The methodology of culture and value distribution in pesantren based-madrasah is coducted through several approaches. One approach that applies in the International Standard Boarding School of Amanatul Ummah (ISB Amanatul Ummah) is through the obligation to wear santri's dresses cap and sarong as the santri's dress in their daily life in pesantren environment. Dress expresses a particular community identity, in which dress is one of the most distinct marking ranges of a person's outward appearance [4].

This study is intended to analyze the impact of wearing typical dresses of santri on the behavior of male students in the
ISB Amanatul Ummah as part of character education in pesantren to disseminate and distribute the characters of santri.

\section{Methodology}

This study applied a descriptive analysis approach, which connects the research phenomena (variables) based on facts from the researcher's observation on the object of research [5]. Furthermore, the analytical model in analyzing the main topics in this article applied a model of cause and effect analysis through a rational approach that is arranged based on observations that are confirmed by literature review. The applied method follows the systematics of SULTHAN flow analysis model, as presented in Fig. 1.

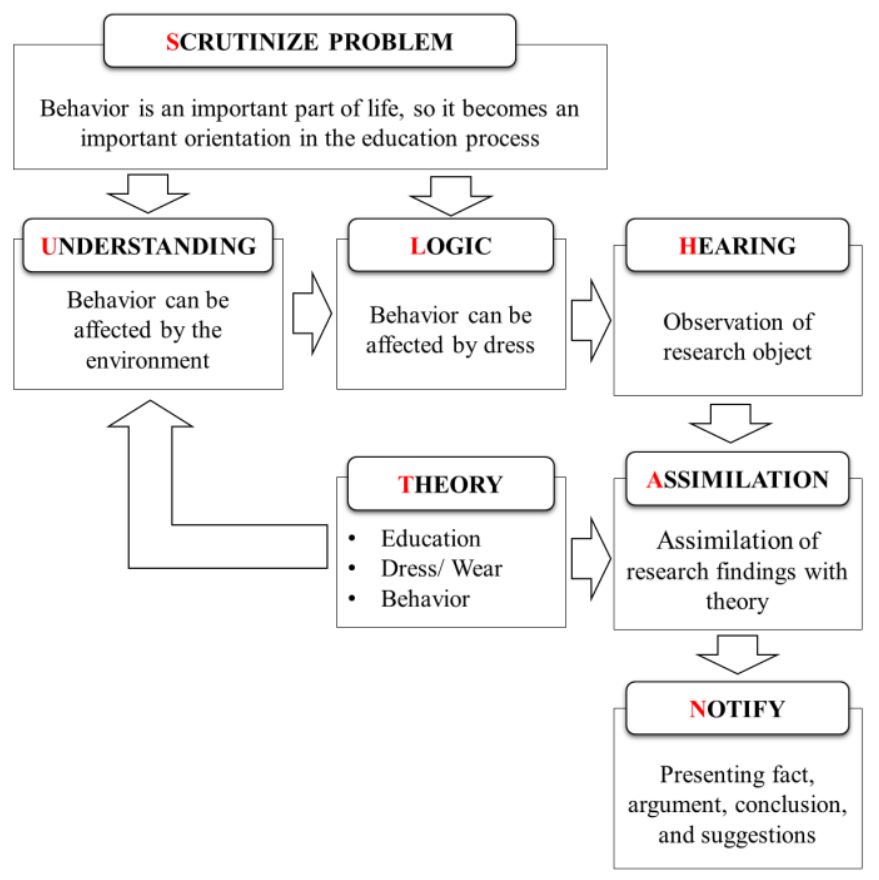

Fig. 1. Research logical framework.

The object of this study is class $\mathrm{X}$ students at the ISB Amanatul Ummah, Mojokerto. They are the santri community. Santri are teenager's student who have their own choices or their parents' choices to study at Islamic boarding school 
(pesantren) [6]. Adolescence is a period of transition ranged from childhood to adulthood, in which most of their life orientation is directed at the acceptance of their identity to peers and adults. Researchers acted as participant observers, where the first author of this article is a class $\mathrm{X}$ student at the ISB Amanatul Ummah, Mojokerto.

\section{RESULTS AND DISCUSSION}

The educational model implemented in the ISB Amanatul Ummah is a pesantren based-boarding school model. Pesantren is an educational system that conducts activities throughout the day, santri live in dormitories in one area together with their teachers, kyai, and seniors [7]. This model is directed to produce qualified graduates, in addition to having good skills in science and technology, they have good religious skills. The purpose of education in the ISB Amanatul Ummah is forming pious and intelligent people that have a noble character and skills beneficial for humans.

The education system that applies in the ISB Amanatul Ummah is The 24-hour-Care System and Muadalah, which provides 24 hour education services. The learning process in the ISB Amanatul Ummah covers the formal learning process and religious reinforcement through the implementation of Islamic lessons (diniyah) of Al-Azhar (Egypt) curriculum, salat (obligatory and sunnah), tahqiq, Islamic extracurricular (memorizing Al-Qur'an, banjari, calligraphy and Arabic language).

The pattern of character education developed in the ISB Amanatul Ummah is done through instilling religious character in all learning and learners activities, including discipline and sanction enforcement both in school and dormitory. Although it seems relatively new, this pesantren succeeded to make proud achievements that cover scholarship awardee in Ministry of Religious Affairs and $98 \%$ of its students can continue to the State Universities [8].

Character education is the development of the learner's ability to behave well which is characterized by the improvement of several abilities that will make human a divine creature (submittion to the concept of divinity), and bear mandate as a leader of the world [9, 10]. The nature of character education is the process of guiding learners to change behavior, attitudes, and cultures, which eventually will create a civilized community [11]. Character education covers three main elements: knowing the good, loving the good, and doing the good [12].

Behavior is basically the actualization of the values that someone adopted into action. it is necessary for behavior to be controlled by a value system that contains goodness, so in this context, there can be seen the urgency of religion and culture as the control of behavior and personality.

Based on the researcher's observation, the religious environment condition has an impact on the santri's behavior, in which santri community that live in the pesantren environment formed a social system that influence the behavior of students. Some of the community values become the individual values of santris formed from the pesantren environment in the ISB Amanatul Ummah that include patience, attention, togetherness, responsibility, ethics, learning enthusiasm, and persistence. This is in line with Ramdhani's appointment which states that character education is influenced by the environment [13].

The most apparent attribute that shows the identity of santri in the ISB Amanatul Ummah is santri's wearing distinctive dresses, cap and sarong, as one of the santri's ethics and obligations while they are staying in the pesantren environment. The dressing identity can establish a conducive environment in the character formation of santri.

As matter of fact, dress or fashion is one of the basic element of human life. Dress can have a psychological impact on its wearer. For instance, Judges in some countries use wigs so as to give the impression of authority in front of present audiences. In Indonesia for example, some people deliberately wear turban to give the impression of religious piety or perseverance. In addition, some young people who deliberately tear off their jeans or wear a necklace on their necks to impress at least their peers, that they are "funky" young men and follow the trend [4]. Moreover, Santri wear his distinctive dress to show and present his identity as a muslim who is studying religion.

Dress is a part of the wearer's identity, which is believed that the use of a typical dress will affect the behavior of the wearer and can reflect the emotion of the wearer, in which at the same time can affect the emotions of others. As a result, it is assumed that if santri use his distinctive dress, he will not be away from the value embedded in his identity.

For further development, dress is a concept of the signifier and meaning of one's identity which covers: prestige, dignity, and social status. Additionally, dress becomes a means of communication, humans communicate in an indirect way without a necessarily personal approach. Dresses in social culture can not be separated from the values within a society.

Ethics covers human's actions and behavior that is ruling dress patterns. Therefore, there are some necessary standards to be followed in wearing dresses that cover aurat. Since ethics is related to social systems, dress ethics not only covers the nakedness and protects the wearer from climate and temperature, but also gives the impression to the wearer. The social system in Indonesia has determined the tendency of cap and sarong users to be the identity of a good Muslim. The value can derives from religious teachings or cultural values established from a generation to another generation by the ancestors as a legacy held by a community [4].

Based on the researcher's observation, santri that wears cap and sarongs tend to have good character, such as being polite (keeping their views and words), more patient, and eliminating social class among santri. In sum, this research reveals that character education can be performed through dressing approach that possibly control santri's behavior.

In some certain cases, based on interviews with teachers in the ISB Amanatul Ummah, the violations of dress ethics in pesantren environments can serve an indicator that a particular santri has behavior problems, when he does not obey the dress code. 
One research finding shows that behavior can be formed by reward-punishment system. The higher a reward is earned or will be earned, the more likely a behavior will be repeated. The higher the cost or punishment to be gained, the less likely the similar behavior will be repeated; there is an existing chain relationship between the various stimuli and responses.

\section{CONCLUSION}

The research finding showed that the santri's dressing has a cultural value that positively affects the behavior of santri. This research recommends the habituation of santri dress with reward and punishment mechanism as a control to the obedience of santri in pesantren environment.

\section{REFERENCES}

[1] M. A. Ramdhani, D. Djamaluddin, and H. Ainissyifa, "Building Moderate Attitude through Character Education," in International Conference on Islam in Malay World V, Songkla, 2015.

[2] E. Supriatna, E. Bahruddin, D. Hafidhuddin, and D. Saefuddin, "Konsep dan Implementasi Pendidikan Karakter di Sekolah Menengah Kejuruan (SMK) Berbasis Pondok Pesantren," Ta'dibuna: International Journal of Islamic Education, vol. 3, no. 2, pp. 16-30, 2014.

[3] E. M. Syafitri, F. Indrasari, and N. Lisdiantini, "Perilaku Melanggar Tata Tertib Berbusana pada Mahasiswa Administrasi Bisnis di Kampus Politeknik Negeri Madiun," Epicheirisi, vol. 1, no. 1, pp. 29-34, 2017.
[4] V. F. Bangit, "Orientasi Nilai Budaya di Kalangan Perempuan terhadap Model Pakaian di Kota Manado," HOLISTIK, vol. 10, no. 19, pp. 1-25, 2017.

[5] M. A. Ramdhani and A. Ramdhani, Penelitian Pemasaran, Bandung: UIN Sunan Gunung Djati Bandung, 2016.

[6] H. Susanto and M. Muzakki, "Perubahan Perilaku Santri: Studi Kasus Alumni Pondok Pesantren Salafiyah di Desa Langkap, Kecamatan Besuki, Kabupaten Situbondo," Istawa: Jurnal Pendidikan Islam, vol. 2, no. 1, pp. 1-42, 2016.

[7] B. Prayitno, B. Sumardjoko, and Waston, "Kontribusi Motivasi Belajar Dan Kreativitas Terhadap Kemandirian Belajar Santri Kulliyatul Muallimin Al-Islamiyah Pondok Pesantren Ta'mirul Islam Surakarta Tahun 2016/2017," Universitas Muhammadiyah Surakarta, Surakarta, 2017.

[8] L. Magfiroh and Mudjito, "Pembinaan Karakter Religius Islami Berbasis Asrama di Madrasah Aliyah Bertaraf Internasional Amanatul Ummah Mojokerto," Inspirasi Manajemen Pendidikan, vol. 1, no. 2, pp. 1-8, 2017.

[9] D. Kesuma, C. Triatna, and J. Permana, Pendidikan Karakter: Kajian Teori dan Praktik di Sekolah, Bandung: Remaja Rosdakarya, 2013.

[10] M. A. Ramdhani and H. Muhammadiyah, "The Criteria of Learning Media Selection for Character Education in Higher Education," in International Conference of Islamic Education in Southeast Asia, Malang, 2015.

[11] A. Z. Aushop, Islamic Character Building: Membangun Insan Kamil, Cendekia Berakhlak Qurani, Bandung: Grafindo Media Pratama, 2014.

[12] H. Ainissyifa, "Pendidikan Karakter dalam Perspektif Pendidikan Islam," Jurnal Pendidikan Universitas Garut, vol. 8, no. 1, pp. 1-26, 2014.

[13] M. A. Ramdhani, "Lingkungan Pendidikan dalam Implementasi Pendidikan Karakter," Jurnal Pendidikan Universitas Garut, vol. 8, no. 1, pp. 27-36, 2014. 